\title{
Influence of sodium intake and sociodemographic, lifestyle and anthropometric variables on blood cholesterol of hypertensive women
}

\author{
Influência da ingestão de sódio e de variáveis sociodemográficas, de estilo de \\ vida e antropométricas no colesterol sérico de mulheres hipertensas
}

Bruna Merten Padilha ${ }^{1}$ (D), Sandra Mary Lima Vasconcelos ${ }^{1}$ (D), Poliana Coelho Cabral ${ }^{2}$ (D), Thiago Marques Wanderley ${ }^{1}$ (D) Amanda da Silva Gomes ${ }^{1}$ (D), Joice Alves Gaia ${ }^{1}$ (D), Letícia Andrade Rodrigues ${ }^{1}$ (D)

\begin{abstract}
The restriction of sodium intake, one of the pillars of antihypertensive treatment, has been associated with the increase in cholesterol levels. Given this, we hypothesize that a sodium intake restriction may increase cholesterol levels in hypertensive women. The present study aimed to evaluate the influence of sodium intake, sociodemographic, lifestyle and anthropometric variables on the blood cholesterol levels of hypertensive women. This was a cross-sectional study with hypertensive and nondiabetic women aged 20 to 59 years, recruited from the primary healthcare units of Maceio, Alagoas, in the Brazilian Northeast. Sodium intake was estimated by the 24-hour urinary excretion of sodium; and blood cholesterol was estimated by capillary blood. Age (years), education level ( $<4$ or $\geq 4$ years), race (white or nonwhite), smoking and alcohol consumption were evaluated. The weight, height and waist circumference were measured and body mass index, conicity index and waist-to-height ratio were quantified. The percentage of body fat was measured using a tetrapolar bioelectrical impedance device. The relationship between blood cholesterol and other variables was assessed by multiple regression analysis. A significance level of $5 \%$ was used in the final model. This study included 165 hypertensive women. In linear regression, blood cholesterol was directly proportional to age $(p<0.001)$, education level $(p=0.01)$ and race $(p=0.04)$. These variables, as well as sodium intake $(p=0.07)$ and conicity index $(p=0.12)$, were included in the multiple regression analysis. Sodium intake $(p=0.03)$ and age $(p=0.001)$ were related, in an inverse and a direct way, respectively, to the blood cholesterol in the hypertensive women studied.
\end{abstract}

Keywords: Age, Anthropometry, Cholesterol, Hypertension, Obesity.

\begin{abstract}
RESUMO
A restrição da ingestão de sódio, um dos pilares do tratamento anti-hipertensivo, tem sido associada ao aumento dos níveis de colesterol. Diante disso, levantou-se a hipótese de que a ingestão de sódio influencia os níveis de colesterol de mulheres hipertensas, independentemente de outros fatores associados. Trata-se de um estudo transversal realizado com mulheres hipertensas e não diabéticas, na faixa etária entre 20 e 59 anos, recrutadas em unidades básicas de saúde de Maceió, Alagoas, situada no Nordeste do Brasil. A ingestão de sódio foi estimada pela excreção urinária de sódio de 24 horas; e o colesterol sérico foi mensurado por coleta de sangue capilar. Foram avaliados idade (anos), escolaridade ( $<4$ ou $\geq 4$ anos), raça (branca ou não branca), tabagismo e consumo de álcool. O peso, a estatura e a circunferência da cintura foram aferidos e o índice de massa corporal, índice de conicidade e razão cintura/estatura foram calculados. A porcentagem de gordura corporal foi medida usando um dispositivo de impedância bioelétrica tetrapolar. A relação entre o colesterol sérico e as outras variáveis em estudo foi avaliada por meio de análise de regressão múltipla, adotando-se um nível de significância de $5 \%$ no modelo final. Este estudo incluiu 165 mulheres hipertensas. Na análise de regressão linear, o colesterol sérico foi relacionado à idade $(p<0,001)$, escolaridade $(p=0,01)$ e raça $(p=0,04)$. Essas variáveis, assim como o consumo de sódio $(p=0,07)$ e o índice de conicidade $(p=0,12)$, foram incluídas na análise de regressão múltipla. As variáveis que permaneceram no modelo final foram ingestão de sódio $(p=0,03)$ e idade $(p=0,001)$. A ingestão de sódio e a idade foram as variáveis que influenciaram o colesterol sérico de mulheres hipertensas.
\end{abstract}

Palavras-chave: Idade, Antropometria, Colesterol, Hipertensão, Obesidade.

Federal University of Alagoas. Faculty of Nutrition. Maceió, (AL), Brasil

Federal University of Pernambuco. Departament of Nutrition. Recife, (PE), Brasil 


\section{INTRODUCTION}

Systemic arterial hypertension (SAH) is a multifactorial clinical disease considered a serious public health problem [1], which substantially increases the risk of developing other cardiovascular diseases (CVD) [2]. These diseases are one of the leading causes of death in the world [3].

Among the risk factors associated with CVD are those considered non-modifiable, such as age, gender and genotype, and those considered modifiable, such as dietary, smoking, stress, weight gain and sedentary lifestyle [4]. One of these main risk factors is cholesterol, whose high serum concentrations are associated with the development of endothelial dysfunction and atherosclerosis [5].

Since most hypertensive individuals present hypercholesterolemia and this condition further increases the risk of CVD $[6,7]$, the knowledge of the factors that influence blood cholesterol in hypertensive women is an important measure to prevent or retard these diseases in this group.

It is known that diet and lifestyle are factors that contribute to the increase of levels of blood cholesterol [7]. Considering that reducing sodium intake is one of the pillars of antihypertensive treatment $[8,9,10]$ and given that the restriction of this micronutrient has been associated with an increase in cholesterol levels [11].

Given the above and the fact that 24-hour urine collection is considered the gold standard for estimating sodium intake [12], the present study aimed to evaluate the influence of sodium intake and sociodemographic, lifestyle and anthropometric variables on blood cholesterol of hypertensive women.

\section{METHODS}

This cross-sectional study, conducted between January and September 2015, included 165 hypertensive and nondiabetic women aged 20 to 59 years recruited from primary healthcare units of the city of Maceio, capital of the state of Alagoas in the Brazilian Northeast. Pregnant women and women with genetic or acquired malformations were not included because an anthropometric assessment would not be possible. Women taking lipid-lowering medication were excluded.
The sample size was estimated using the software Epi Info version 6.04, with the following parameters: level of significance of $95 \%(1-a)$, a study power of $80 \%(1-\beta)$, ratio of $1: 1$, considering exposure (hypercholesterolemia) and relative risk equal to 1.5. Based on these criteria, the necessary sample was around 165 women, whose selection was for convenience, and acquisition was by adhesion.

Sociodemographic, anthropometric, biochemical, and blood pressure data were collected. The self-reported races were grouped as white and nonwhite. Education level, based on full years of formal education, was classified as very low ( $<4$ years) and low ( $\geq 4$ years).

Anthropometric assessment consisted of measuring weight, height, and waist circumference (WC). The measurements were performed twice, by the same researcher, and averaged. New measurements were performed when the two weight, height, and WC measurements, differed by more than $100 \mathrm{~g}, 0.5 \mathrm{~cm}$, and $0.3 \mathrm{~cm}$, respectively.

Weight and height were measured as originally recommended by Lohman et al. [13], using the electronic portable scale Lider ${ }^{\circledR}$ model P200M (maximum capacity of $200 \mathrm{~kg}$ and accuracy of 50 g) and the portable stadiometer Seca ${ }^{\circledR}$ and its inelastic metric tape measure (length of $2 \mathrm{~m}$, graduated to $0.1 \mathrm{~cm}$ ). Body mass index (BMI) was calculated by dividing weight by the square of the height. Using the cut-off points provided by the World Health Organization (WHO) [14], women with BMI below $25.0 \mathrm{~kg} / \mathrm{m}^{2}$ were categorized as "without excess weight," and those with BMI equal to or above $25.0 \mathrm{~kg} / \mathrm{m}^{2}$, as "with excess weight."

WC was measured by the inelastic metric fiberglass tape measure Sanny ${ }^{\circledR}$, with a length of $150 \mathrm{~cm}$, graduated to $0.1 \mathrm{~cm}$, at the midpoint between the lowest rib and the iliac crest at the end of a normal expiration [14]. The waist-to-height ratio (WHtR) and the conicity index (C index) were calculated. $C$ index was given by the formula: $C$ index $=W C(m) /[0,109 \times \sqrt{ }($ weight $(\mathrm{kg}) /$ height $(m))]$. These indices have been described as the best anthropometric predictors of cardiovascular risk [12]. Women with $W C \geq 80 \mathrm{~cm}$ [14], WHtR $\geq 0.50$ [15] and C index $\geq 1.18$ [16] were considered at risk of developing metabolic complications associated with obesity. 
The percentage of body fat (BF) was calculated by the body composition assessment software CompCorp $\AA$ based on body resistance and reactance was measured by the tetrapolar bioelectrical impedance device RJL model 101-A, as recommended by Lukaski et al.[17]. To indicate above-average body fat levels, the Gallagher et al. [18] classification was used.

Capillary blood was collected by disposable microcuvettes between 08:00 $\mathrm{h}$ and 10:00 h after a twelve-hour fast using Accu-Check $\AA$ (Roche $\AA$ ) test strips and the portable monitor Accutrend GTC $\AA$ (Roche $\AA$ ), which measures cholesterol in the 150 to $300 \mathrm{mg} / \mathrm{dL}$ range. The results were obtained immediately with the reading of the device and interpreted according to the V Brazilian Guidelines on Dyslipidemias and Prevention of Atherosclerosis [19], considering altered cholesterol levels above $200 \mathrm{mg} / \mathrm{dL}$.

To determine sodium intake, the participants were asked to collect urine during a full 24-hour period, starting with the second urine on day one and ending with the first urine on day two. Urine was collected in a $5 \mathrm{~L}$ container provided by the researchers. When done, the participants returned the containers to their primary healthcare unit. The women were asked not to change their diets during the 24-hour urine collection period.

The analysis consisted of (1) measuring urine volume using a $1000 \mathrm{~mL}$ beaker; (2) collecting one $0.5 \mathrm{~mL}$ aliquot of urine using $1 \mathrm{ml}$ pipettes and pipette pump; (3) placing the aliquot in one $6 \mathrm{~mL}$ test tube; (4) measuring sodium concentration using the ion-selective electrode Iselab ${ }^{\circledR}$, with automatic aspiration, a built-in printer, and automatic calibration and cleaning systems.

The urine samples of patients who failed to collect one or more urinations, containers with less than $500 \mathrm{~mL}$ of urine, and urine collected outside of the 23-25-hour period were discarded, as they were considered incomplete and/or inappropriate [20].

The biochemical marker of sodium intake is the 24-hour urinary sodium excretion (24hUNaE), as more than $90 \%$ of the ingested sodium is excreted in the urine [21]. The $24 \mathrm{hUNaE}$ is given by the formula: $24 \mathrm{hUNaE}(\mathrm{mmol} / \mathrm{L})=24$-hour urine volume $(\mathrm{mL}) \times$ excreted $\mathrm{Na}(\mathrm{mmol}) / 1000.24 \mathrm{hUNaE}$ in $\mathrm{mmol} / \mathrm{L}$ was converted into $\mathrm{mg} / \mathrm{L}$ by multiplying it by sodium's molar mass $(\mathrm{Na}=23 \mathrm{~g})$.
Blood pressure (BP) was measured as recommended by the VII Joint National Committee of Hypertension [22] by the automatic digital device Omron ${ }^{\circledR}$ model HEM 705 CP, validated as instructed by international protocol. In cases where there was a difference greater than 5 $\mathrm{mmHg}$ between two measures of systolic blood pressure (SBP) or diastolic blood pressure (DBP), a third one was performed, neglecting the most discrepant. The value adopted for the analyses was the result of the average of the two valid measures. Values of SBP $\geq 140 \mathrm{mmHg}$ and of DBP $\geq 90 \mathrm{mmHg}$ were considered as high blood pressure levels [22].

Statistical analyses were performed by the software Epi Info version 6.04 (CDC/WHO, Atlanta, GE, USA) and by the software SPSS version 13.0 (SPSS Inc., Chicago, IL, USA). The Kolmogorov-Smirnov test checked the normality of the continuous variables. Since these variables had normal distribution, they were expressed as mean and standard deviation. The proportions and their respective $95 \%$ confidence intervals were also calculated $(95 \% \mathrm{CI})$.

Linear regression analysis was performed between blood cholesterol and sodium intake (g), age (years), education level ( $<4$ years or $\geq 4$ years), race (white or nonwhite), smoking (smoker and non-smoker), alcohol consumption (does not use, sporadic use and daily consumption), BMI $\left(\mathrm{kg} / \mathrm{m}^{2}\right), \mathrm{WC}, \mathrm{WHtR}, \mathrm{C}$ index and BF. This analysis aimed to evaluate the relationship between blood cholesterol (dependent variable) and the other variables (independent variables) and to select those to be used in multiple regression analysis at a level of $20 \%$ significance. Variables with a significance level of $5 \%(p<0.05)$ were considered significant for the final model.

This study was sponsored by a scientific research-funding agency owned by the state and complied with human research rules established by Resolution n. 466/2012 of the National Health Council. The study was approved in 2013 by the Research Ethics Committee of the Federal University of Alagoas (CAAE: 19203313.2.0000.5013). All women who agreed to participate in the study signed a consent form after being informed of the possibilities of risk and discomfort associated with the procedures. 


\section{RESULTS}

A total of 191 hypertensive women were assessed. Of these, 18 (9.4\%) were excluded because their 24-hour urine collections were incomplete, and $8(4.2 \%)$, because their blood cholesterol data were missing. Hence, the study included 165 hyper-

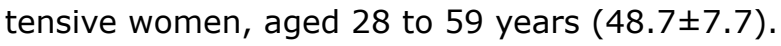

There was a predominance of nonwhite race $(n=138 ; 83.6 \%)$ and educational levels higher than 4 years $(n=103 ; 62.4 \%)$. The majority reported that they were not smokers $(n=148,89.7 \%)$ or alcohol users ( $n=129,78.2 \%$ ) (Table 1 ).

The use of antihypertensive medication was reported by 156 (94.5\%) (Table 1 ). Nevertheless, 75 (45.5\%) presented elevated SBP and DBP and $133(80.6 \%)$ had a higher sodium intake than rec- ommended. Biochemical tests revealed that 80 (48.5\%) had altered cholesterol levels. Anthropometric evaluation and body composition assessment showed that $134(81.2 \%)$ were overweight according to BMI, and $115(69.7 \%)$ had elevated BF levels (Table 2).

In linear regression (Table 3 and Figure 1 ), blood cholesterol was directly proportional to age $(p<0.001)$, education level $(p=0.01)$ and race $(p=0.04)$. These variables, as well as sodium intake $(p=0.07)$ and conicity index $(p=0.12)$, were included in the multiple regression analysis.

From the multivariate analysis (Table 4), an adjusted $R^{2}$ coefficient of 0.14 ( $\left.p<0.001\right)$ was found. The variables that remained in the final model were sodium intake $(\beta=-3.30, p=0.03)$ and age $(\beta=1.43, p=0.001)$.

Table 1. Sociodemographic, lifestyle and clinical data of hypertensive women.

\begin{tabular}{|c|c|c|c|}
\hline Variables & $\mathbf{n}$ & $\%$ & $95 \% \mathrm{CI}$ \\
\hline \multicolumn{4}{|l|}{ Age (years) } \\
\hline 45 to 59 & 118 & 71.5 & $63.9-78.1$ \\
\hline 20 to 44 & 47 & 28.5 & $21.9-36.1$ \\
\hline \multicolumn{4}{|l|}{ Race } \\
\hline Nonwhite & 138 & 83.6 & $76.9-88.8$ \\
\hline White & 27 & 16.4 & $11.2-23.1$ \\
\hline \multicolumn{4}{|l|}{ Education level } \\
\hline Very low & 62 & 37.6 & $30.3-45.5$ \\
\hline Low & 103 & 62.4 & $54.5-69.7$ \\
\hline \multicolumn{4}{|l|}{ Smoking } \\
\hline Yes & 17 & 10.3 & $6.3-16.2$ \\
\hline No & 148 & 89.7 & $83.8-93.7$ \\
\hline \multicolumn{4}{|l|}{ Alcohol consumption } \\
\hline Daily consumption & 10 & 6.1 & $3.1-11.2$ \\
\hline Sporadic use & 26 & 15.8 & $10.7-22.4$ \\
\hline Does not use & 129 & 78.2 & $70.9-84.1$ \\
\hline \multicolumn{4}{|c|}{ Use of antihypertensive medication } \\
\hline Yes & 156 & 94.5 & $89.6-97.3$ \\
\hline No & 9 & 5.5 & $2.7-10.4$ \\
\hline
\end{tabular}

$\mathrm{n}$ - number of individuals; $95 \%, \mathrm{Cl}-95 \%$ confidence interval. 
Table 2 - Blood pressure, biochemical and anthropometric data of hypertensive women.

\begin{tabular}{|c|c|c|c|}
\hline Variables & $\mathbf{n}$ & $\%$ & $95 \% \mathrm{CI}$ \\
\hline \multicolumn{4}{|l|}{ Systolic blood pressure (SBP) } \\
\hline Altered $(\mathrm{SBP} \geq 140 \mathrm{mmHg})$ & 75 & 45.5 & $37.8-53.4$ \\
\hline Normal & 90 & 54.5 & $46.6-62.2$ \\
\hline Mean \pm Standard Deviation & \multicolumn{3}{|c|}{$141.1 \mathrm{mmHg} \pm 22.9$} \\
\hline \multicolumn{4}{|l|}{ Diastolic blood pressure (DBP) } \\
\hline Altered $(\mathrm{DBP} \geq 90 \mathrm{mmHg})$ & 75 & 45.5 & $37.8-53.4$ \\
\hline Normal & 90 & 54.5 & $46.6-62.2$ \\
\hline Mean \pm Standard Deviation & \multicolumn{3}{|c|}{$87.7 \mathrm{mmHg} \pm 13.2$} \\
\hline \multicolumn{4}{|l|}{ Sodium (Na) intake } \\
\hline Altered ( $\mathrm{Na}>2 \mathrm{~g} / \mathrm{dia})$ & 133 & 80.6 & $73.6-86.2$ \\
\hline Normal & 32 & 19.4 & $13.8-26.4$ \\
\hline Mean \pm Standard Deviation & \multicolumn{3}{|c|}{$3.7 \mathrm{~g} \pm 1.9$} \\
\hline \multicolumn{4}{|l|}{ Blood cholesterol (C) } \\
\hline Altered $(C \geq 200 \mathrm{mg} / \mathrm{dL})$ & 80 & 48.5 & $40.7-56.4$ \\
\hline Normal & 85 & 51.5 & $43.6-59.3$ \\
\hline Mean \pm Standard Deviation & \multicolumn{3}{|c|}{$202.7 \mathrm{mg} / \mathrm{dL} \pm 41.3$} \\
\hline \multicolumn{4}{|l|}{ Body mass index (BMI) } \\
\hline With excess weight $\left(B M I \geq 25.0 \mathrm{~kg} / \mathrm{m}^{2}\right)$ & 134 & 81.2 & $74.2-86.7$ \\
\hline Without excess weight & 31 & 18.8 & $13.3-25.8$ \\
\hline Mean \pm Standard Deviation & \multicolumn{3}{|c|}{$30.8 \mathrm{~kg} / \mathrm{m}^{2} \pm 6.4$} \\
\hline \multicolumn{4}{|l|}{ Waist circumference (WC) } \\
\hline With risk $(\mathrm{WC} \geq 80 \mathrm{~cm})$ & 146 & 88.5 & $82.4-92.7$ \\
\hline Without risk & 19 & 11.5 & $7.2-17.6$ \\
\hline Mean \pm Standard Deviation & \multicolumn{3}{|c|}{$96.0 \mathrm{~cm} \pm 14.0$} \\
\hline \multicolumn{4}{|l|}{ Waist to height ratio (WHtR) } \\
\hline With risk (WHtR $\geq 0.50)$ & 152 & 92.1 & $86.6-95.6$ \\
\hline Without risk & 13 & 7.9 & $4.4-13.4$ \\
\hline Mean \pm Standard Deviation & \multicolumn{3}{|c|}{$0.62 \pm 0.1$} \\
\hline \multicolumn{4}{|l|}{ Conicity index ( $C$ index) } \\
\hline With risk ( $C$ index $\geq 1.18$ ) & 142 & 86.1 & $79.6-90.8$ \\
\hline Without risk & 23 & 13.9 & $9.2-20.4$ \\
\hline Mean \pm Standard Deviation & & \multicolumn{2}{|c|}{$1.28 \pm 0.1$} \\
\hline \multicolumn{4}{|l|}{ Body fat (BF)* } \\
\hline With risk & 115 & 69.7 & $62.0-76.5$ \\
\hline Without risk & 50 & 30.3 & $23.5-38.0$ \\
\hline Mean \pm Standard Deviation & \multicolumn{3}{|c|}{$36.5 \% \pm 8.2$} \\
\hline
\end{tabular}

$\mathrm{n}$ - number of individuals; $95 \% \mathrm{Cl}$ - 95\% confidence interval; ${ }^{*}$ Gallager et al. $(2000)^{16}$. 
Table 3 - Simple linear regression analysis between blood cholesterol and independent variables.

\begin{tabular}{lcccc}
\hline & \multicolumn{3}{c}{ Blood cholesterol $\mathbf{( m g / d L )}$} & \\
\cline { 2 - 5 } Independent variables & $\beta$ & $\mathbf{9 5 \%} \mathbf{c I}$ & $\mathbf{p}$ & $\mathbf{R}^{2}$ \\
\hline Sodium intake $(\mathrm{g})$ & -2.91 & $-6.11-0.29$ & 0.07 & 0.01 \\
Age (years) & 1.76 & $0.96-2.53$ & $<0.001$ & 0.10 \\
Education level* & 17.03 & $4.13-29.93$ & 0.01 & 0.03 \\
Race (white or nonwhite) & 17.49 & $0.47-34.51$ & 0.04 & 0.02 \\
Smoking (yes or no) & -0.68 & $-21.6-20.29$ & 0.95 & -0.01 \\
Alcohol consumption** & -0.19 & $-15.63-15.24$ & 0.98 & -0.01 \\
Body mass index $\left(\mathrm{kg} / \mathrm{m}^{2}\right)$ & -0.20 & $-1.19-0.80$ & 0.70 & -0.01 \\
Waist circumference $(\mathrm{cm})$ & 0.14 & $-0.32-0.60$ & 0.54 & -0.00 \\
Waist to height ratio & 27.44 & $-39.07-93.94$ & 0.42 & -0.00 \\
Conicity index & 45.27 & $-11.49-102.03$ & 0.12 & 0.01 \\
Body fat (\%) & 0.02 & $-0.77-0.82$ & 0.96 & -0.01 \\
\hline
\end{tabular}

"Classified as $<4$ or $\geq 4$ full years of formal education; ${ }^{* \star}$ Classified as does not use, sporadic use and daily consumption.
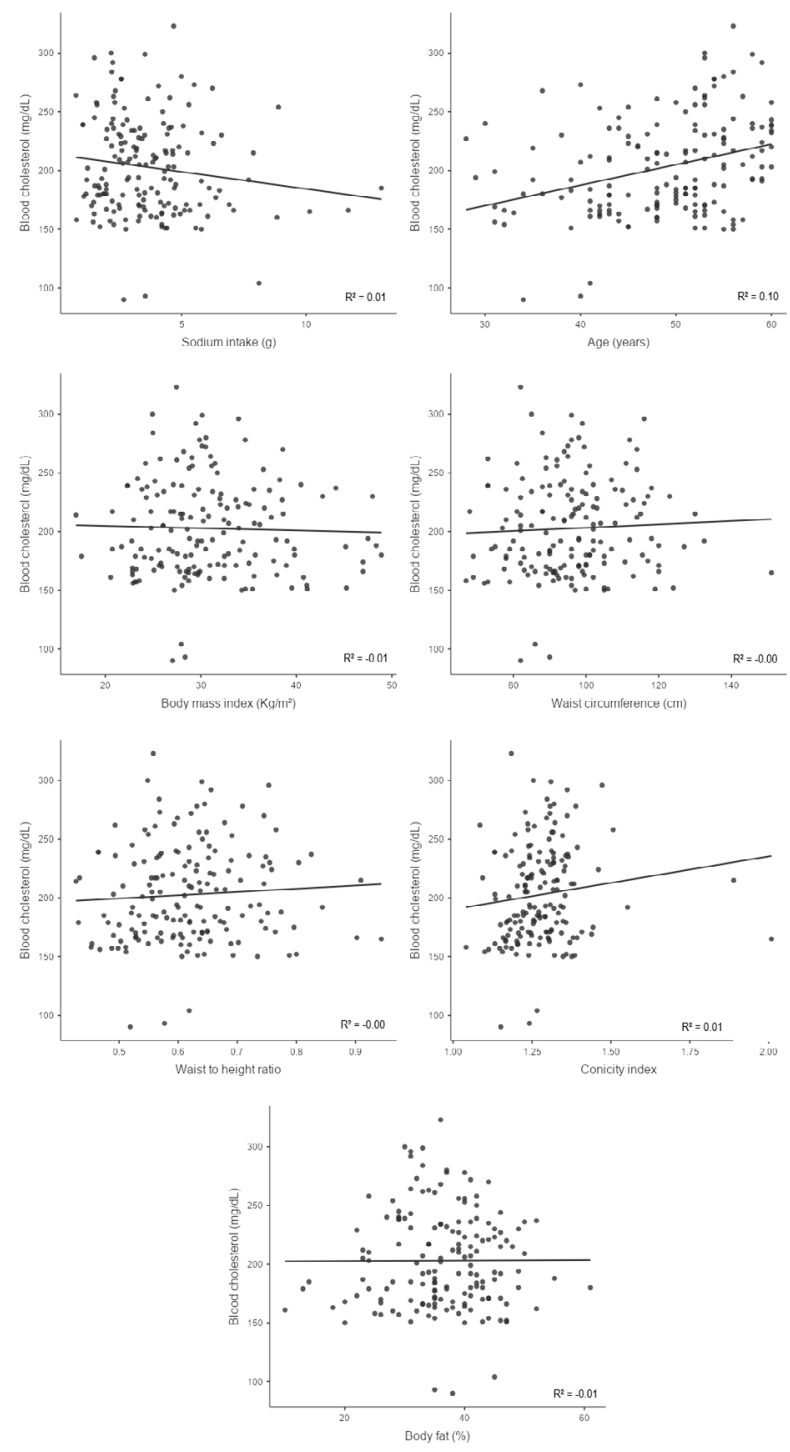

Figure 1 - Simple linear regression analysis between blood cholesterol and continuous variables. 
Table 4 - Multiple linear regression analysis between blood cholesterol and independent variables.

\begin{tabular}{lccc}
\hline & \multicolumn{3}{c}{ Blood cholesterol $(\mathbf{m g} / \mathbf{d L})$} \\
\cline { 2 - 4 } Independent variables & $\beta$ & $\mathbf{9 5 \% C I}$ & $\mathbf{p}$ \\
\hline Sodium intake $(\mathrm{g})$ & -3.30 & $-6.37--0.23$ & 0.03 \\
Age (years) & 1.43 & $0.61-2.24$ & 0.001 \\
Education level* $^{*}$ & 12.91 & $-0.005-25.82$ & 0.05 \\
Race (White or nonwhite) & 12.08 & $-4.14-28.30$ & 0.13 \\
\hline Conicity index & 23.46 & $-30.81-77.72$ & 0.39 \\
\hline
\end{tabular}

"Classified as $<4$ or $\geq 4$ full years of formal education

Adjusted $\mathbf{R}^{2}$ for the model $=0.14(p<0.001)$

\section{DISCUSSION}

The findings show that sodium intake and age had an influence on blood cholesterol of hypertensive women. The direct relationship between age and blood cholesterol is already well documented in the literature and is explained by different mechanisms [23]. With aging, there is a decline in the rate of bile acid synthesis, an increase in the number of mediators that aid in the absorption of cholesterol in the intestine and oxidative stress, which favors the increase of blood cholesterol [24].

Because the participants were already hypertensive women, where hypertension per se is a cardiovascular risk factor [25] and it is known that the prevalence of CVD increases with age [26], special attention needed to be given to the relationship found.

An inverse relationship between sodium intake and blood cholesterol, as evidenced in this stu$\mathrm{dy}$, has been described in meta-analyses $[11,27]$. In these, it was observed that the limited intake of sodium reduces body water content and increases the levels of epinephrine, renin and angiotensin, aiming at the correction of low plasma volume. However, these hormones inhibit insulin, causing insulin resistance [11] and, consequently, hyperinsulinemia, which compromises lipid metabolism and promotes an increase in cholesterol levels $[28,29]$.

Insulin resistance is known to be a marker of multiple metabolic abnormalities frequently associated with SAH. This condition is common in individuals with excess weight and accumulation of abdominal fat [28], the condition of the majority of the hypertensive women investigated. This homogeneity of the sample may have compromised the occurrence of a statistically significant relationship between the anthropometric indices evaluated and the blood cholesterol.

Although cholesterol is a lipid that plays important roles in the body, in excessive levels and abnormal metabolism, it favors the development of CVD [7]. Aiming at the reduction of blood pressure and consequently the prevention of cardiovascular outcomes, sodium restriction is one of the pillars of antihypertensive therapy $[8,9,10]$. However, if this restriction favors the increase of blood cholesterol, which, in turn, is also associated with the development of CVD, would the hypertensive patient be benefiting, in fact, from this restriction?

A low sodium diet, despite being advocated for over a century [24], is still one of the major challenges of antihypertensive therapy. Restricting the use of sodium in food alters the palatability and the pleasure of eating [31], which may lead to reduced dietary and nutritional deficiencies.

Our findings agree with the positive relationship already elucidated in the literature between age and blood cholesterol and reinforce the need for further studies to elucidate the metabolic effects of sodium restriction in antihypertensive treatment and to explore the need for this restriction.

The main limitation of the present study is the fact that only hypertensive individuals were evaluated, making it impossible to compare the data found with those of normotensive individuals.

\section{CONCLUSION}

In conclusion, sodium intake and age were related, in an inverse and a direct way, respectively, to the blood cholesterol in the hypertensive women studied. 


\section{REFERENCES}

1. Susic D, Varagic J. Obesity: a perspective from hypertension. Med Clin North Am. 2017; 101:139-157.

2. Sverre EK. Hypertension and cardiovascular risk: General aspects. Pharmacological Research. 2018; 129:95-99.

3. GBD 2017 Causes of Death Collaborators. Global, regional, and national age-sex-specific mortality for 282 causes of death in 195 countries and territories, 1980-2017: a systematic analysis for the Global Burden of Disease Study 2017. The Lancet. 2018;392(10159):1736-1788.

4. Koene RJ, Prizment AE, Blaes A, Konety SH. Shared Risk Factors in Cardiovascular Disease and Cancer. Circulation. 2016;133(11):1104-1114.

5. Wang T, Butany J. Pathogenesis of atherosclerosis. Diagnostic Histopathology. 2017;23(11):473-478.

6. Egan BM, Li J, Qanungo S, Wolfman TE. Blood pressure and cholesterol control in hypertensive hypercholesterolemic patients: NHANES 1988-2010. Circulation. 2013;128(1):29-41.

7. Dudum R, Juraschek SP, Appel LJ. Dose-dependent effects of lifestyle interventions on blood lipid levels: Results from the PREMIER trial. Patient Education and Counseling. 2019;102(10):1882-1891.

8. Malachias MVB, Souza WKSB, Plavnik FL, Rodrigues CIS, Brandão AA, Neves MFT, et. al. 7a Diretriz Brasileira de Hipertensão Arterial. Arq Bras Cardiol. 2016;107(3) (supl.3):1-104.

9. Whelton PK, Carey RM, Aronow WS, Casey DE, Collins KJ, Himmelfarb CD, et. al. 2017 ACC/AHA/AAPA/ABC/ ACPM/AGS/APhA/ASH/ASPC/NMA/PCNA Guideline for the Prevention, Detection, Evaluation, and Management of High Blood Pressure in Adults. J Am Coll Cardiol. 2018;71(19):127-248.

10. Williams B, Mancia G, Spiering W, Rosei EA, Azizi M, Burnier $M$, et al. 2018 ESC/ESH Guidelines for the management of arterial hypertension. European Heart Journal. 2018; 39:3021-3104.

11. Graudal NA, Hubeck-Graudal T, Jurgens G. Effects of lowsodium diet vs. high-sodium diet on blood pressure, renin, aldosterone, catecholamines, cholesterol, and triglyceride (Cochrane Review). Am J Hypertens. 2017; 25:1-15.

12. Motamed N, Perumal D, Zamani F, Ashrafi H, Haghjoo M, Saeedian FS, et.al. Conicity index and waist-to-hip ratio are superior obesity indices in predicting 10-year cardiovascular risk among men and women. Clin cardiol. 2015;38(9):527-534.

13. Lohman TG, Roche AF, Martorell R. Anthropometric standardization reference manual. Champaign: Human Kinetics Books; 1988.

14. World Health Organization (WHO). Obesity: preventing and managing the global epidemic. Report of a World Health Organization Consultation. Geneva: WHO; 2000. (WHO Obesity Technical Report Series 284).
15. Ashwell MS, Hsieh D. Six reasons why the waist-to-height ratio is a rapid and effective global indicator for health risks of obesity and how its use could simplify the international public health message on obesity. Int J Food Sci Nutr. 2005; 56:303-307.

16. Pitanga FG, Lessa, I. Sensitivity and specificity of the conicity index as a coronary risk predictor among adults in Salvador, Brazil. Rev Bras Epidemiol. 2004;7(3):259269.

17. Lukaski HC, Johnson PE, Bolonchuk WW, Lykken G. Assessment of fat-free mass using bioelectrical impedance measurements of human body. Am J Clin Nutr. 1985;41: 810-817.

18. Gallagher D. Healthy percentage body fat ranges: an approach for developing guidelines based on body mass index. Am J Clin Nutr. 2000;72:694-701.

19. Xavier HT, Izar MC, Neto JRF, Assad MH, Rocha V, Sposito AC.et. al. V Diretriz Brasileira de Dislipidemias e Prevenção da Aterosclerose. Arq Bras Cardiol. 2013; 101(4):136.

20. Rodrigues SL, Souza Júnior PR, Pimentel EB, Baldo MP, Malta DC, Mill JG et al. Relationship between salt consumption measured by 24-h urine collection and blood pressure in the adult population of Vitória (Brazil). Braz J Med Biol Res. 2015;48(8):728-735.

21. McLean RM. Measuring population sodium intake: a review of methods. Nutrients. 2014; 6:4651-4662.

22. Chobanian AV, Bakris GL, Black HR, Cushman WC, Green LA, Izzo JL, et.al. National High Blood Pressure Education Program Coordinating Committee. The national high blood pressure education program coordinating. The Seventh Report of the Joint National Committee on Prevention, Detection, Evaluation, and Treatment of High Blood Pressure: The JNC 7 Report. JAMA. 2003; 289(19):25602571.

23. Odden MC, Rawlings AM, Arnold AM, Cushman M, Biggs ML, Psaty BM, et. al. Patterns of Cardiovascular Risk Factors in Old Age and Survival and Health Status at 90. J Gerontol A Biol Sci Med Sci. 2020.

24. Morgan AE, Mooney KM, Wilkinson SJ, Pickles NA, McAuley MT. Cholesterol metabolism: A review of how ageing disrupts the biological mechanisms responsible for its regulation. Ageing Res Rev. 2016; 27:108-124.

25. Diabetes Care. Cardiovascular Disease and Risk Management. Diabetes Care. 2017;40(Suppl. 1):75-87.

26. Ende MYV, Hartman MHT, Hagemeijer $Y$, Meems LMG, Vries HS, Stolk RP, et. al. The LifeLines Cohort Study: Prevalence and treatment of cardiovascular disease and risk factors. International Journal of Cardiology. 2017; 228:495-500.

27. Graudal NA, Hubeck-Graudal T, Jurgens G. Effects of lowsodium diet vs. high-sodium diet on blood pressure, renin, aldosterone, catecholamines, cholesterol, and triglyceride (Cochrane Review). Am J Hypertens. 2012; 25:1-15. 
28. Soleimani M. Insulin resistance and hypertension: new insights. Kidney Int. 2015; 87:497-499.

29. Silva AA, Carmo JM, Li X, Wan Z, Mouton AJ, Hall JE. Role of hyperinsulinemia and insulin resistance in hypertension: metabolic syndrome revisited. Canadian Journal of Cardiology. 2020;36(5):671-682.
30. Rust $P$, Ekmekcioglu C. Impact of salt intake on the pathogenesis and treatment of hypertension. Adv Exp Med Biol. 2017; 956:61-84.

31. Leshem M. Salt need needs investigation. British Journal of Nutrition. 2020; 123(11):1312-1320.

\section{Acknowledgements}

this study was supported by the Research Support Foundation of the state of Alagoas (Fundação de Amparo à Pesquisa do Estado de Alagoas).

The English text of this paper has been revised by Sidney Pratt, Canadian, MAT (The Johns Hopkins University), RSAdip - TESL (Cambridge University).

\section{Disclosure}

The authors declared no conflict of interest.

Corresponding author:

Bruna Merten Padilha

bruna48@hotmail.com

Editor:

Prof. Dr. Marcelo Riberto

Received in: jun 02, 2020

Approved in: apr 01, 2021 